\section{Association between perceived racial discrimination and hypertension: findings from the ELSA-Brasil study}

\section{A associação entre discriminação racial percebida e hipertensão: achados do estudo ELSA-Brasil}

\author{
Asociación entre la discriminación racial \\ percibida y la hipertensión: hallazgos \\ del estudio ELSA-Brasil
}

Patrícia Miranda Mendes 1,2

Aline Araújo Nobre 3

Rosane Härter Griep 4

Joanna Miguez Nery Guimarães 1

Leidjaira Lopes Juvanhol 5

Sandhi Maria Barreto 6

Alexandre Pereira 7

Dóra Chor 1

doi: 10.1590/0102-311X00050317

\begin{abstract}
"Pardos" and blacks in Brazil and blacks in the USA are at greater risk of developing arterial hypertension than whites, and the causes of this inequality are still little understood. Psychosocial and contextual factors, including racial discrimination, are indicated as conditions associated with this inequality. The aim of this study was to identify the association between perceived racial discrimination and hypertension. The study evaluated 14,012 workers from the ELSA-Brazil baseline population. Perceived discrimination was measured by the Lifetime Major Events Scale, adapted to Portuguese. Classification by race/color followed the categories proposed by Brazilian Institute of Geography and Statistics (IBGE). Hypertension was defined by standard criteria. The association between the compound variable - race/racial discrimination - and hypertension was estimated by Poisson regression with robust variance and stratified by the categories of body mass index (BMI) and sex. Choosing white women as the reference group, in the BMI $<25 \mathrm{~kg} /$ $\mathrm{m}^{2}$ stratum, "pardo" women showed adjusted OR for arterial hypertension of 1.98 (95\%CI: 1.17-3.36) and 1.3 (95\%CI: 1.13-1.65), respectively, whether or not they experienced racial discrimination. For black women, ORs were 1.9 (95\%CI: 1.42-2.62) and 1.72 (95\%CI: 1.36-2.18), respectively, for the same categories. Among women with BMI $>25 \mathrm{~kg} / \mathrm{m}^{2}$ and men in any BMI category, no effect of racial discrimination was identified. Despite the differences in point estimates of prevalence of hypertension between "pardo" women who reported and those who did not report discrimination, our results are insufficient to assert that an association exists between racial discrimination and hypertension.
\end{abstract}

Racism; Social Discrimination; Hypertension

\author{
Correspondence \\ P. M. Mendes \\ Rua dos Mundurucus 4476, Belém, PA 66073-005, Brasil. \\ pmendes@ufpa.br \\ 1 Escola Nacional de Saúde Pública Sergio Arouca, \\ Fundação Oswaldo Cruz, Rio de Janeiro, Brasil. \\ 2 Universidade Federal do Pará, Belém, Brasil. \\ 3 Programa de Computação Científica, Fundação Oswaldo \\ Cruz, Rio de Janeiro, Brasil. \\ 4 Instituto Oswaldo Cruz, Fundação Oswaldo Cruz, \\ Rio de Janeiro, Brasil. \\ 5 Departamento de Nutrição e Saúde, Universidade Federal de \\ Viçosa, Viçosa, Brasil. \\ 6 Faculdade de Medicina, Universidade Federal de Minas \\ Gerais, Belo Horizonte, Brasil. \\ 7 Instituto do Coração, Universidade de São Paulo, São Paulo, \\ Brasil.
}




\section{Introduction}

Although it has been recognized since 1930 that hypertension is more prevalent among blacks than whites in the United States, the causes of this disparity are still not completely clear 1,2. In Brazil 3,4,5, differences in prevalence of hypertension by groups defined by race/color (white, "pardo", black, yellow, and indigenous) 6 are being documented, showing that the mortality rate for hypertensive diseases is greater among blacks 7 .

Socioeconomic differences - lack of schooling is one of the main determinants of hypertension 8,9 - can partly explain differences in prevalence among blacks, "pardos" and whites 10,11. However, psychosocial and contextual factors also seem to contribute to differences in the prevalence of hypertension among blacks, "pardos" and whites in Brazil, and among blacks and whites in the United States. In this regard, stress is central to etiological research 11,12,13, especially chronic stress and the discrimination that has been signaled as one of its key components 11,14,15,16. However, results of prior studies, which are concentrated in the United States, are not consistent regarding the existence of an association between racial discrimination and hypertension. A recent review 17 points to substantial methodological limitations in existing studies, suggesting a weak association between racial discrimination and hypertension.

Racial discrimination might lead to unhealthy behaviors (such as physical inactivity and increased energy intake) as coping strategies to deal with discrimination-related stress, resulting in weight gain 18,19. Coping strategies might be different among men and women. Thus, body mass index (BMI) is an important proximal determinant for hypertension risk 20,21,22,23, especially among men 24,25,26.

In Brazil, where $21.4 \%$ of the population over 18 years old (about 31 million people) reported a medical diagnosis of hypertension in 2013, the highest prevalence of medical diagnosis of hypertension occurred among self-reported blacks (24\%), as compared to 22\% among self-reported whites 27. Brazilian studies of racial health inequalities and the association between perceived racial discrimination and health outcomes are quite scarce 3,5,14,28,29. As far as we could determine, the only study published on the subject 3 was based on too small a number of participants to investigate possible differences between "pardos" and blacks for the strength of the association between racial discrimination and hypertension. The Brazilian Longitudinal Study of Adult Health (Estudo Longitudinal de Saúde do Adulto, ELSA-Brasil), the largest longitudinal study of cardiovascular diseases in Brazil, offers a unique opportunity to examine the association between racial discrimination and hypertension in blacks and "pardos" separately. These racial categories are unique to Brazil, and their study can add important knowledge to the subject. The objectives of this study were to investigate the combined effect of racial discrimination and race/color on the occurrence of hypertension and examine the differences in this association according to sex and BMI.

\section{Methods}

\section{Study population}

ELSA-Brasil is a cohort study designed primarily to investigate cardiovascular diseases and diabetes 30,31 . Ongoing in six research centers located in Brazilian state capitals, its volunteer participants are active and retired civil servants, from 35 to 74 years of age, from the Oswaldo Cruz Foundation (Fiocruz, Rio de Janeiro), the Federal Universities of Espírito Santo (UFES), Minas Gerais (UFMG), Rio Grande do Sul (UFRGS), and Bahia (UFBA), and the University of São Paulo (USP).

This study used data from the first wave of data collection (2008-2010), in which 15,105 participants were interviewed and underwent clinical and anthropometric measurement and laboratory tests 32,33 .

\section{Exclusion criterion}

Participants self-declared as yellow $(\mathrm{n}=374)$ and indigenous $(\mathrm{n}=157)$ were excluded from this study because they constituted a very small portion of the study population, as were white participants 
reporting racial discrimination $(\mathrm{n}=64)$, who represented only $0.8 \%$ of total whites. Those lacking information on exposure $(n=184)$, outcome $(n=21)$ or some other covariable $(n=293)$ were also excluded, leaving a total 14,012 participants.

\section{Data collection and processing}

In ELSA-Brazil, the recruitment of participants and interviews, clinical exams and the collection, processing, storage and transfer of biological samples toke place in the six research centers 34 . In addition, all interviews, measurement taking and laboratory testing were performed by trained, certified teams, and all procedures were subject to quality control 35 .

\section{Classification by race/color}

Classification by race/color was achieved by asking the following question: "The Brazilian Census (Brazilian Institute of Geography and Statistics - IBGE) uses the terms "black", "pardo", "white", "yellow", and "indigenous" to classify people's color or race. If you were to answer the IBGE census today, how would you classify yourself regarding your color or race?"

\section{Racial discrimination}

Perceived discrimination was ascertained using an adaptation of the Lifetime Major Events Scale 36 comprising five questions, all starting with the same phrase: "Have you ever felt you were treated unfairly because of discrimination...", "...in your workplace, such as being fired, not being hired for a job, or not being appointed to a leadership position?", "...in matters relating to housing, such as having difficulty renting or getting along with neighbors?", "...by the police, such being accused, searched or suffering aggression of some kind?", "...in public places, such as banks, commercial establishments, hospitals, government offices and so on", and "...at your school or college, such as being discouraged from continuing your education?".

Participants who reported experiencing discrimination were then asked: "The last time this happened, what - in your opinion - was the reason for that discrimination? (If necessary mark more than one option)". The following response options were offered: your color or race; you being a man or woman; your religion or creed; disease or physical disability; your sexual orientation or preference; your economic status, education or function; your political activity; your age; your physical appearance; and other. The test-retest reliability study (yes/no discrimination) of the version used in this study had a value of 0.85 (kappa coefficient) in a similar population 3 .

\section{Construction of the exposure variable (racial discrimination and race/color)}

The exposure is a compound measure formed by combining the variables self-classification by race/ color (white, "pardo", and black) and perceived racial discrimination (yes or no), and classified into 5 categories: "White who reported no racial discrimination" (reference), "pardo who reported racial discrimination" ("pardo"; yes), "pardo"” who reported no racial discrimination” ("pardo”; no), "black who reported racial discrimination" (black; yes) and "black who reported no racial discrimination" (black; no). Participants who reported discrimination for other reasons (other than color or race) were included in the category "did not report racial discrimination", as were those who reported no discrimination for any reason.

\section{Outcome (hypertension)}

Systolic and diastolic arterial pressure were measured using a validated oscillometric monitor (Omron HEM 705CPINT - Omron Healthcare, São Paulo, Brazil), after the participant had rested for five minutes seated in a calm room at controlled temperature $\left(20-24^{\circ} \mathrm{C}\right)$. Three measurements were taken at one-minute intervals, and the mean of the last two was recorded. Quality assurance and control procedures were implemented in all study centers to minimize measurement errors 33 , and reliability analysis was satisfactory: the intraclass correlation coefficient for systolic pressure was estimated at 
0.88 (95\%CI: 0.82-0.91) and, for diastolic pressure, at 0.89 (95\%CI: 0.83-0.92) 35. Information about continuous medication use in the two weeks prior to the interview was recorded. Participants were instructed to bring prescriptions and/or packages of medicines used, which were examined by the interviewer. The medicines were classified as antihypertensives according to a standardized list, and categorized by their main pharmacological action: diuretics, beta-blockers, calcium channel blockers, angiotensin-converting-enzyme inhibitors, angiotensin II antagonists, vasodilators, and central and peripheral sympatholytics 4 .

To be considered a antihypertensive medication user, the participant had to report using at least one of the medicines classified as antihypertensives, and also to answer "yes" to the question "of the medicines you have taken in the past two weeks, were any for hypertension (high blood pressure)?”

Hypertension was considered present if the participant met at least one of three criteria: systolic arterial pressure $\geq 140 \mathrm{mmHg}$ or diastolic arterial pressure $\geq 90 \mathrm{mmHg}$ or antihypertensive medicine use in the two weeks prior to the interview.

\section{Covariables}

In line with the literature 1,8,9,37, the following covariables were considered: age (continuous, in years), sex, schooling (incomplete secondary education, complete secondary education, and higher education), family history of hypertension (yes/no), research center, and body mass index (BMI) $(<25 \mathrm{~kg} /$ $\mathrm{m}^{2}$ and $\geq 25 \mathrm{~kg} / \mathrm{m}^{2}$ ). All covariables were collected by interview ${ }^{32}$, except BMI (weight measured in $\mathrm{kg}$ divided by the square of the height measured in meters) 38 . Family history of hypertension was collected from participants' answers to the question: "Did or does any of these relatives (father, mother) have hypertension (high blood pressure)?”.

\section{Theoretical model}

Built on a broad theoretical model, a directed acyclic graph (Figure 1) identified a minimum set of adjustment variables. Research centers were included as confounders because they represented the participants' places of residence and, therefore, different proportions of racial composition (which may affect both self-classification by race/color and perceived discrimination, as well as other unknown differences), in addition to regional variations in prevalence of hypertension. BMI was considered a possible mediator, because of its importance as a proximal risk factor for hypertension. Family history of hypertension was not included as an adjustment variable because it correlates with exposure and displays association only with the outcome. The theoretical model was constructed using the DAGitty software, v. 2.3 (http://www.dagitty.net/) 39.

\section{Statistical analysis}

Descriptive analyses were conducted to display the characteristics of the study population and ageadjusted prevalence of hypertension.

The association between racial discrimination/race and hypertension was estimated using a Poisson regression model with robust variance 40. Prevalence ratio (PR) and 95\% confidence intervals (95\%CI) were calculated from the crude and adjusted models (Model 1: crude; Model 2: adjusted for age; Model 3: adding schooling; and Model 4: adding research center).

An interaction term between racial discrimination/race and sex was tested. The result was borderline ( $\mathrm{p}=0.05$ ), but nonetheless the analyses were stratified by sex. Results were stratified according to BMI since adjustment would not be consistent with our theoretical model. Statistical analyses were performed using the R software (The R Foundation for Statistical Computing, Vienna, Austria; http:// www.r-project.org).

\section{Ethical considerations}

ELSA-Brasil was approved by the ethics committees of each participating institution. All participants signed a declaration of free and informed consent. 


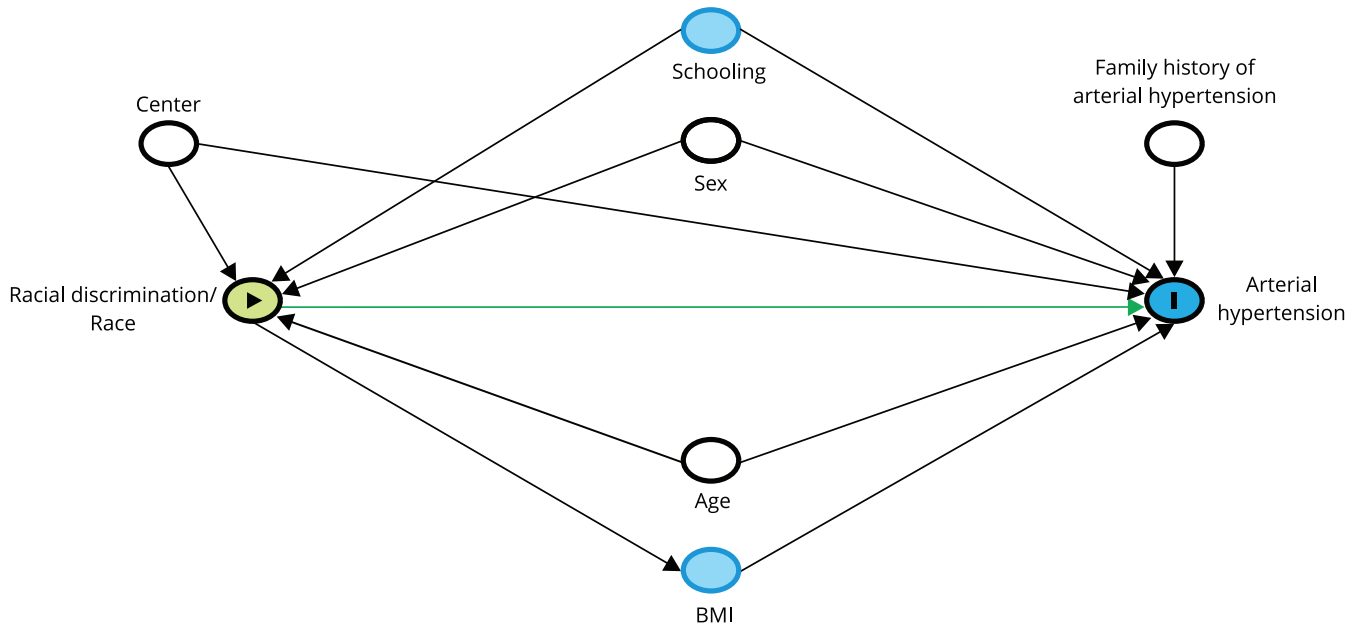

BMI: body mass index.

\section{Results}

Of the overall population, the majority were women (54.8\%), as were self-reported whites (54\%), followed by "pardos" (29.4\%) and blacks (16.6\%) (Table 1). A total of 990 (7.1\%) participants reported racial discrimination in the course of their lives; out of these, $74.1 \%(\mathrm{n}=734)$ were black. Most of the population (52.5\%) were college-educated: $54.1 \%$ of women and $50.5 \%$ of men. Likewise, most of the population (63.3\%) were overweight, more so among men (65.9\%) than women (61.1\%). Black participants displayed greater prevalence of age-adjusted hypertension, both men $(50.8 \%)$ and women (46.5\%), followed by "pardos" and whites. "Pardo" participants who reported discrimination displayed higher prevalence of hypertension (43.9\%) than non-discriminated "pardo" (38.1\%), but proportions among blacks showed no significant difference, whether (47.3\%) or not (48.6\%) they reported discrimination, respectively. Prevalence of hypertension was inversely associated to the level of schooling, ranging from $29.9 \%$ (higher education) to $44.3 \%$ (incomplete secondary education); inverse gradients were observed among both men (45.9\% and $34.9 \%$ ) and women (41.8\% and $26.1 \%)$. Lastly, the prevalence of hypertension directly increased with BMI bracket.

The models for the association between race/racial discrimination and hypertension are shown in Table 2. In the model adjusted for all covariables (Model 4), the associations - for both men and women - were stronger among those with $\mathrm{BMI}<25 \mathrm{~kg} / \mathrm{m}^{2}$ than among the overweight.

Among men with BMI $<25 \mathrm{~kg} / \mathrm{m}^{2}$, prevalence was greater among blacks than among whites, whether or not the former reported ( $\mathrm{PR}=1.48 ; 95 \% \mathrm{CI}: 1.12-1.96)$ or $\operatorname{did}$ not report $(\mathrm{PR}=1.37 ; 95 \% \mathrm{CI}$ : 1.109-1.73) racial discrimination. However, there was no statistically significant difference by racial discrimination. There was no difference between "pardo" men who reported racial discrimination and the reference category (white men, no discrimination). Among overweight men, the prevalence of hypertension was greater among black than among white men, with no difference between groups that did or did not report racial discrimination.

Among women, in the group with BMI $<25 \mathrm{~kg} / \mathrm{m}^{2}$, black participants who reported racial discrimination displayed higher prevalence of hypertension ( $\mathrm{PR}=1.93$; 95\%CI: 1.42-2.62) than those who did not report discrimination ( $\mathrm{PR}=1.72$; 95\%CI: 1.36-2.18). Among "parda" women, the difference was even greater: prevalence among those who reported racial discrimination was $98 \%$ higher 
Study population characteristics and prevalence of age-adjusted hypertension. ELSA-Brasil, 2008-2010 (N = 14.012).

\begin{tabular}{|c|c|c|c|c|c|c|}
\hline & \multicolumn{2}{|c|}{ Men $(n=6,334)$} & \multicolumn{2}{|c|}{ Women $(n=7,678)$} & \multicolumn{2}{|c|}{ Total $(\mathrm{N}=14,012)$} \\
\hline & Total & Hypertension & Total & Hypertension & & Hypertension \\
\hline \multicolumn{7}{|l|}{ Race } \\
\hline White & $3,466(54.7)$ & $1,277(35,3)$ & $4,105(53.5)$ & $1,069(25,7)$ & $7,571(54.0)$ & $2,346(30,1)$ \\
\hline "Pardo" & $1,966(31.0)$ & $798(42,8)$ & $2,148(28.0)$ & $722(34,5)$ & $4,114(29.4)$ & $1,520(38.5)$ \\
\hline Black & $902(14.2)$ & $452(50.8)$ & $1,425(18.5)$ & $660(46.5)$ & 2,327 (16.6) & $1,112(48.2)$ \\
\hline \multicolumn{7}{|l|}{ Racial discrimination } \\
\hline Yes & $448(7.1)$ & $201(48.2)$ & $542(7.1)$ & $228(45.0)$ & $990(7.1)$ & $429(46.4)$ \\
\hline No & $5,886(92.9)$ & $2,326(39,2)$ & $7,136(92.9)$ & $2,223(31,0)$ & $13,022(92.9)$ & $4,549(34.7)$ \\
\hline \multicolumn{7}{|l|}{ Race; discrimination } \\
\hline White & $3,466(54.7)$ & $1,277(35.3)$ & $4,105(53.5)$ & $1,069(25.7)$ & $7,571(54.0)$ & $2,346(30.1)$ \\
\hline “Pardo”; no & $1,822(28.8)$ & $737(42,6)$ & $2,036(26.5)$ & $679(34.1)$ & $3,858(27.5)$ & $1,416(38.1)$ \\
\hline “Pardo"; yes & $144(2.3)$ & $61(45.8)$ & $112(1.5)$ & $43(41.4)$ & $256(1.8)$ & $104(43.9)$ \\
\hline Black; no & $598(9.4)$ & $312(51.6)$ & 995 (12.9) & 475 (46.7) & $1,593(11.4)$ & 787 (48.6) \\
\hline Black; yes & $304(4.8)$ & $140(49.4)$ & $430(5.6)$ & $185(45.9)$ & $734(5.2)$ & $325(47.3)$ \\
\hline \multicolumn{7}{|l|}{ Schooling } \\
\hline Incomplete secondary education & $1,004(15.8)$ & $521(45.9)$ & $723(9.4)$ & $387(41.8)$ & $1,727(12.3)$ & $908(44.3)$ \\
\hline Complete secondary education & $2,130(33.6)$ & $860(44.2)$ & $2,798(36.4)$ & $1,013(37.8)$ & $4,928(35.2)$ & $1,873(40.6)$ \\
\hline Higher education & $3,200(50.5)$ & $1,146(34.9)$ & $4,157(54.1)$ & $1,051(26,1)$ & $7,357(52.5)$ & 2,197 (29.9) \\
\hline \multicolumn{7}{|l|}{$\mathrm{BMI}\left(\mathrm{kg} / \mathrm{m}^{2}\right)$} \\
\hline$<25$ & $2,161(34.1)$ & $569(26.8)$ & $2,988(38.9)$ & $558(26,8)$ & $5,149(36.7)$ & $1,127(23.0)$ \\
\hline$\geq 25$ & $4,173(65.9)$ & $1,958(46.5)$ & $4,690(61.1)$ & $1,893(38.9)$ & $8,863(63.3)$ & $3,851(42.5)$ \\
\hline \multicolumn{7}{|l|}{ Family history of hypertension } \\
\hline No & $2,118(33.4)$ & $603(27.2)$ & $1,510(19.7)$ & $297(18,2)$ & $3,628(25.9)$ & $900(23.4)$ \\
\hline Yes & $4,216(66.6)$ & $1,924(46.3)$ & $6,168(80.3)$ & $2,154(35.5)$ & $10,384(74.1)$ & 4,078 (39.9) \\
\hline
\end{tabular}

BMI: body mass index.

* Age-adjusted.

than among white women ( $\mathrm{PR}=1.98$; 95\%CI: 1.17-3.36) and, among those who did not, 36\% higher $(\mathrm{PR}=1.36$; 95\%CI: 1.13-1.65). Among overweight women, prevalence was higher only among blacks, but there was no difference between the group of those who reported racial discrimination $(\mathrm{PR}=1.39$; 95\%CI: 1.24-1.57) and those who did not (PR = 1.38; 95\%CI: 1.25-1.51).

\section{Discussion}

It cannot be asserted if there is an association between experiencing racial discrimination and the prevalence of hypertension. We did not observe significant changes in the association investigated even with progressive adjustments. Only among "parda" women with BMI $<25 \mathrm{~kg} / \mathrm{m}^{2}$, when compared to white women, was the association stronger for those who reported discrimination than for those who did not. Among men, the associations were weaker or not significant. Hence, while on the one hand these results confirm that black and "pardo" participants, especially women, displayed higher prevalence of hypertension than whites, racial discrimination does not seem to be one of the explanatory factors of that difference in this study population.

Prior studies of the association between perceived racial discrimination and hypertension have not produced consistent results. One of the reasons for these divergences is the numerous different scales used to measure racial discrimination, which has limited the understanding of its impact on 


\section{Table 2}

Prevalence ratios (PR) and $95 \%$ confidence intervals $(95 \% \mathrm{Cl})$ for the association between perceived racial discrimination and arterial hypertension, stratified by sex and body mass index (BMI). ELSA-Brasil, $2008-2010$ ( $N=14,012)$.

\begin{tabular}{|c|c|c|c|c|}
\hline \multirow{3}{*}{$\begin{array}{l}\text { Models [Race/color; perceived } \\
\text { racial discrimination (yes/no)] }\end{array}$} & \multicolumn{2}{|c|}{ Men } & \multicolumn{2}{|c|}{ Women } \\
\hline & $\begin{array}{c}\mathrm{BMI}<25 \mathrm{~kg} / \mathrm{m}^{2} \\
(\mathrm{n}=2,161)\end{array}$ & $\begin{aligned} B M I & \geq 25 \mathrm{~kg} / \mathrm{m}^{2} \\
(\mathrm{n} & =4,173)\end{aligned}$ & $\begin{array}{c}\mathrm{BMI}<25 \mathrm{~kg} / \mathrm{m}^{2} \\
\quad(\mathrm{n}=2,988)\end{array}$ & $\begin{array}{c}\text { BMI } \geq 25 \mathrm{~kg} / \mathrm{m}^{2} \\
\quad(\mathrm{n}=4,690)\end{array}$ \\
\hline & PR $(95 \% \mathrm{Cl})$ & PR $(95 \% \mathrm{Cl})$ & PR $(95 \% \mathrm{Cl})$ & PR $(95 \% \mathrm{Cl})$ \\
\hline \multicolumn{5}{|l|}{ Model 1: crude } \\
\hline White; no & 1.00 & 1.00 & 1.00 & 1.00 \\
\hline “Pardo”; no & $1.35(1.15-1.59)$ & $1.05(0.97-1.13)$ & $1.42(1.19-1.70)$ & $1.15(1.06-1.26)$ \\
\hline "Pardo"; yes & $1.37(0.87-2.15)$ & $1.08(0.88-1.34)$ & $2.24(1.37-3.67)$ & $1.16(0.88-1.53)$ \\
\hline Black; no & $1.83(1.48-2.25)$ & $1.29(1.18-1.42)$ & $2.10(1.71-2.58)$ & $1.55(1.42-1.70)$ \\
\hline Black; yes & $1.64(1.21-2.21)$ & $1.13(0.98-1.30)$ & $1.81(1.33-2.47)$ & $1.42(1.26-1.62)$ \\
\hline \multicolumn{5}{|l|}{ Model 2: + age } \\
\hline White; no & 1.00 & 1.00 & 1.00 & 1.00 \\
\hline “Pardo"; no & $1.51(1.30-1.75)$ & $1.15(1.07-1.24)$ & $1.55(1.31-1.84)$ & $1.19(1.09-1.29)$ \\
\hline “Pardo"; yes & $1.69(1.08-2.64)$ & $1.20(0.98-1.47)$ & $2.20(1.31-3.72)$ & $1.32(1.01-1.72)$ \\
\hline Black; no & $1.73(1.42-2.69)$ & $1.37(1.25-1.49)$ & $2.05(1.68-2.50)$ & $1.57(1.45-1.71)$ \\
\hline Black; yes & $1.74(1.33-2.27)$ & $1.31(1.14-1.50)$ & $2.14(1.59-2.88)$ & $1.59(1.41-1.78)$ \\
\hline \multicolumn{5}{|l|}{ Model 3: + age + schooling } \\
\hline White; no & 1.00 & 1.00 & 1.00 & 1.00 \\
\hline “Pardo”; no & $1.34(1.14-1.58)$ & $1.10(1.01-1.18)$ & $1.47(1.24-1.75)$ & $1.12(1.03-1.22)$ \\
\hline “Pardo"; yes & $1.48(0.94-2.32)$ & $1.15(0.94-1.40)$ & $2.11(1.25-3.56)$ & $1.27(0.98-1.64)$ \\
\hline Black; no & $1.45(1.17-1.80)$ & $1.27(1.16-1.41)$ & $1.86(1.50-2.31)$ & $1.43(1.31-1.56)$ \\
\hline Black; yes & $1.55(1.18-2.03)$ & $1.24(1.08-1.43)$ & $2.02(1.48-2.74)$ & $1.50(1.33-1.69)$ \\
\hline \multicolumn{5}{|l|}{ Model 4: + age + schooling + center } \\
\hline White; no & 1.00 & 1.00 & 1.00 & 1.00 \\
\hline “Pardo”; no & $1.30(1.09-1.54)$ & $1.06(0.98-1.16)$ & $1.36(1.13-1.65)$ & $1.09(1.00-1.19)$ \\
\hline "Pardo"; yes & $1.40(0.88-2.23)$ & $1.14(0.93-1.40)$ & $1.98(1.17-3.36)$ & $1.25(0.97-1.62)$ \\
\hline Black; no & $1.37(1.09-1.73)$ & $1.24(1.12-1.38)$ & $1.72(1.36-2.18)$ & $1.38(1.25-1.51)$ \\
\hline Black; yes & $1.48(1.12-1.96)$ & $1.23(1.07-1.42)$ & $1.93(1.42-2.62)$ & $1.39(1.24-1.57)$ \\
\hline
\end{tabular}

health 11,41. Paradies 42 reported that only one-third of studies apply any of the more commonly used scales, while some investigations have created their own measurement instruments.

In the United States, Barksdale et al. ${ }^{3}$, Peters 44 and Davis et al. 43 have also reported a lack of association. However, their samples were small (respectively, 211, 162, and 356 Afro-Americans), and each used a different scale to measure racial discrimination, all different from the scale used in this study. Brown 45, with a sample of 3,300 women of various different races from the Study of Women's Health Across the Nation and using the Everyday Discrimination Scale, also found no association between the discrimination perceived by different ethnic-racial groups and high pressure levels.

Meanwhile, Sims et al. 46 reported association between hypertension and discrimination when using questions based on the Lifetime Discrimination Scale and Burden of Discrimination, but not when measured by the Everyday Discrimination Scale. Ryan et al. 47 , using an adaptation of the Reactions to Race module 48, found an association between perceived racial discrimination and hypertension, as did Sims et al. 46, Krieger \& Sidney 49, and Brondolo et al. 11. In Brazil, the only study found on the subject categorized participants as whites or blacks (i.e., "pardos" and blacks were grouped together), and its results show a positive association 3 .

Findings of a recent review 11 showed differences between the associations of interpersonal racism and structural racism with hypertension: while the former involves acts, such as suspicion and disrespect, committed by identifiable individuals 50,51, the latter involves differentiated access to 
services, good and opportunities, such as quality education 50,51. In the case of interpersonal racism, the evidence of association with hypertension is weak, while for institutional racism it is stronger, especially regarding residential segregation and imprisonment. In a review published in 2014, Doleszar et al. 17 concluded that there is a slight but significant association between perceived racial discrimination and hypertension, primarily affecting blacks, when nocturnal pressure is measured using ambulatory blood pressure monitoring.

In Brazil, until the 1970s, racial inequalities were mainly attributed to social class differences between racial groups, rather than to prejudice or discrimination. The idea of a "racial democracy" prevailed, and it was not until after the military dictatorship that black activists and social scientists demonstrated it to be wrong 52,53,54. On that account, there is limited awareness in Brazilian society of the existence of discrimination, and studies of its relationship with health are scarce and recent.

Perceived racial discrimination in Brazil, as in other countries, depends - among other things on the identity expressed in racial self-classification 55. In Brazil, self-classification has resulted from various factors, from the proportion of blacks (or whites) in a given town, the individual's socioeconomic status and social background, through to a period in history when race relations can be discussed more often and emphasized by the black movement 56,57. The proportion of individuals who classify themselves as "pardo" or black has grown over the past two decades 52 , possibly reflecting an increasingly stronger black identity in Brazil, which will probably also have affected perceived racial discrimination. According to baseline results of the ELSA-Brazil study (2008-2010), out of the 15,105 participants $37 \%$ reported having suffered at least one episode of discrimination for whatever reason, 48\% among blacks, 37\% among "pardos" and 33\% among whites (results not shown).

The results of this study, which suggest a lack of association between racial discrimination and hypertension, may be because participants who actually were discriminated against because of race failed to perceive it or to attribute it to that reason. Such misclassification could partly explain the lack of association found here. Bearing in mind the possibility that discrimination may be attributed to other reasons (e.g., socioeconomic status, physical appearance), we examined for association between discrimination for any reason and hypertension, and also - in isolation - discrimination attributed to reasons other than race and hypertension. In both cases, no association with the outcome was observed. In addition, we performed analyses after excluding 4,500 participants from the reference category for having reported other reasons for discrimination, which could "contaminate" the reference group by introducing the effect of chronic stress into this category. In this case, no association was found. The exception was "pardo" women discriminated against because of race and with $\mathrm{BM}<25 \mathrm{~kg} / \mathrm{m}^{2}$, who displayed a higher point prevalence ratio than those who had not been discriminated against, when both groups were compared to white women. These results cannot be compared with those of the other Brazilian study cited 3, because the latter examined "pardos" and blacks together. To date, there are no other Brazilian studies to confirm and to help explain this finding. Future research is needed to understand the specifics of "pardos", regarding both health and sociological features 55 .

\section{Advantages and limitations}

This is the largest study conducted in Brazil to assess the association between racial discrimination and hypertension. The number and diversity of participants regarding race/color, socioeconomic status and sex allowed for more refined analyses (of strata by sex and BMI). Thus, this is the first study in Brazil to compare results for "pardos" separately from blacks, which is an important distinction when discussing racial health inequalities. In addition, arterial pressure, weight and height were measured, and use of medicines was ascertained by medical prescription or packaging. All these procedures and the continuous quality guarantee and control process in tests, measurements and interviews made it possible to obtain highly accurate data.

Although the instrument used to measure discrimination was an adaptation of the Lifetime Major Events Scale, which is widely used in the United States, it is not possible to disregard the possibility that that instrument may not be the best suited to examining "pardos" and blacks separately in Brazil. Hence, future research should test other instruments to measure racial discrimination in Brazil. 
In addition to the limitations of the available set of measures of discrimination, the use of the casual blood pressure measurement may be another source of discrepant results, since stronger associations are observed with ambulatory blood pressure monitoring 17,58. The association between racial discrimination and hypertension is reported especially among blacks when nocturnal pressure is used 17 .

Lastly, although we have shown that the association with discrimination was stronger among women with BMI $<25 \mathrm{~kg} / \mathrm{m}^{2}$, this finding should be interpreted with caution, since confidence intervals of discriminated and not discriminated groups overlap.

Studies of the impact of racial discrimination on hypertension in Brazil are needed. Such investigations can help understand health inequalities between and within racial groups, by considering simultaneously socioeconomic and gender aspects. The longitudinal nature of ELSA-Brasil will add new knowledge not captured by cross-sectional analysis.

\section{Contributors}

P. M. Mendes contributed to the study design, data analysis and interpretation, results discussion, and writing. A. A. Nobre contributed to the study design, statistical modelling, interpretation and results discussion, writing, and review of the paper. R. H. Griep contributed to the interpretation of results and review of the paper. J. M. N. Guimarães contributed to the interpretation of results, discussion and review of the paper. L. L. Juvanhol contributed to the interpretation of results, discussion and review of the paper. S. M. Barreto and A. Pereira contributed to the review of the paper. D. Chor contributed to the study design, interpretation of results, discussion, writing and review of the paper. All the authors approved the final version of the paper.

\section{Acknowledgments}

We appreciate the comments and observations that were of great importance for the improvement of the article.

\section{References}

1. Fuchs FD. Why do black Americans have higher prevalence of hypertension?: an enigma still unsolved. Hypertension 2011; 57:379-80.

2. Cooper RS, Forrester TE, Plange-Rhule J, Bovet P, Lambert EV, Dugas LR, et al. Elevated hypertension risk for African-origin populations in biracial societies: modeling the epidemiologic transition study. J Hypertens 2015; 33:473-81.

3. Faerstein E, Chor D, Werneck GL, Lopes CS, Kaplan G. Race and perceived racism, education, and hypertension among Brazilian civil servants: the Pró-Saúde Study. Rev Bras Epidemiol 2014; 17 Suppl 2:81-7.

4. Chor D, Pinho Ribeiro AL, Sá Carvalho M, Duncan BB, Andrade Lotufo P, Araújo Nobre A, et al. Prevalence, awareness, treatment and influence of socioeconomic variables on control of high blood pressure: results of the ELSABrasil study. PLoS One 2015; 10:e0127382.

5. Sichieri R, Oliveira MC, Pereira RA. High prevalence of hypertension among black and mulatto women in a Brazilian survey. Ethn Dis 2001; 11:412-8.

6. Petruccelli JL. Qual a diferença entre preto, pardo e negro? http://noticias.terra.com.br/ educacao/voce-sabia/qual-a-diferenca-entrepreto-pardo-e-negro,395c952757b7e310Vgn VCM5000009ccceb0aRCRD.html (accessed on 13/Jun/2016).

7. Secretaria de Vigilância em Saúde, Ministério da Saúde. Indicadores de vigilância em saúde, analisados segundo a variável raça/cor. http:// portalsaude.saude.gov.br/images/pdf/2015/ abril/22/Boletim-raca-cor-09-04-15-v2.pdf (accessed on 14/Apr/2014). 
8. Gaudemaris R, Lang T, Chatellier G, Larabi L, Lauwers-Cancès V, Maître A, et al. Socioeconomic inequalities in hypertension prevalence and care: the IHPAF Study. Hypertension 2002; 39:1119-25.

9. Hartmann M, Dias-da-Costa JS, Olinto MTA, Pattussi MP, Tramontini A. Prevalência de hipertensão arterial sistêmica e fatores associados: um estudo de base populacional em mulheres no Sul do Brasil. Cad Saúde Pública 2007; 23:1857-66.

10. Jackson JS, Knight KM. Race and self-regulatory behaviors: the role of the stress response and HPA axis in physical and mental health disparities. In: Carstensen LL, Schaie KW, editors. Social structure, aging and self-regulation in the elderly. New York: Springer; 2006. p. 189-207.

11. Brondolo E, Love EE, Pencille M, Schoenthaler A, Ogedegbe G. Racism and hypertension: a review of the empirical evidence and implications for clinical practice. Am J Hypertens 2011; 24:518-29.

12. Hicken MT, Lee H, Morenoff J, House JS, Williams DR. Racial/ethnic disparities in hypertension prevalence: reconsidering the role of chronic stress. Am J Public Health 2014; 104:117-23.

13. Williams DR, Neighbors H. Racism, discrimination and hypertension: evidence and needed research. Ethn Dis 2001; 11:800-16.

14. Bastos JL, Celeste RK, Faerstein E, Barros AJD. Racial discrimination and health: a systematic review of scales with a focus on their psychometric properties. Soc Sci Med 2010; 70: 1091-9.

15. Brondolo E, Gallo LC, Myers HF. Race, racism and health: disparities, mechanisms, and interventions. J Behav Med 2009; 32:1-8.

16. Hertz RP, Unger AN, Cornell JA, Saunders E. Racial disparities in hypertension prevalence, awareness, and management. Arch Intern Med 2005; 165:2098-104.

17. Dolezsar CM, McGrath JJ, Herzig AJM, Miller SB. Perceived racial discrimination and hypertension: a comprehensive systematic review. Health Psychol 2014; 33:20-34.

18. Hickson DA, Lewis TT, Liu J, Mount DL, Younge SN, Jenkins WC, et al. The associations of multiple dimensions of discrimination and abdominal fat in African American adults: the Jackson Heart Study. Ann Behav Med 2012; 43:4-14.

19. Lewis TT, Kravitz HM, Janssen I, Powell LH. Self-reported experiences of discrimination and visceral fat in middle-aged African-American and Caucasian women. Am J Epidemiol 2011; 173:1223-31.

20. Gardner AW, Poehlman ET. Predictors of the age-related increase in blood pressure in men and women. J Gerontol A Biol Sci Med Sci 1995; 50A:M1-6.

21. Dua S, Bhuker M, Sharma P, Dhall M, Kapoor $\mathrm{S}$. Body mass index relates to blood pressure among adults. North Am J Med Sci 2014; 6:89.
22. Doll S, Paccaud F, Bovet P, Burnier M, Wietlisbach V. Body mass index, abdominal adiposity and blood pressure: consistency of their association across developing and developed countries. Int J Obes 2002; 26:48-57.

23. Smith C, Rinderknecht K. Obesity correlates with increased blood pressures in urban native American youth. Am J Hum Biol 2003; 15 : 78-90.

24. Jervase E, Barnabas D, Emeka A, Osondo N. Sex differences and relationship between blood pressure and age among the Ibos of Nigeria. The Internet Journal of Biological Anthropology 2009; 3(2). http://www.ispub. com:80/journal/the-internet-journal-of-bio logical-anthropology/volume-3-number-2/sexdifferences-and-relationship-between-bloodpressure-and-age-among-the-ibos-of-nigeria. html.

25. Silva SSBE, Oliveira SFSB, Pierin AMG. The control of hypertension in men and women: a comparative analysis. Rev Esc Enferm USP 2016; 50:50-8.

26. Pereira M, Lunet N, Azevedo A, Barros H. Differences in prevalence, awareness, treatment and control of hypertension between developing and developed countries. J Hypertens 2009; 27:963-75.

27. Instituto Brasileiro de Geografia e Estatística. Pesquisa Nacional de Saúde, 2013: percepção do estado de saúde, estilos de vida e doenças crônicas: Brasil, grandes regiões e unidades da Federação. ftp://ftp.ibge.gov.br/PNS/2013/ pns2013.pdf (accessed on 13/Jun/2016).

28. Couto PF, Goto JB, Bastos JL. Pressão arterial e discriminação interpessoal: revisão sistemática de estudos epidemiológicos. Arq Bras Cardiol 2012; 99:956-63.

29. Chor D, Lima CRA. Aspectos epidemiológicos das desigualdades raciais em saúde no Brasil. Cad Saúde Pública 2005; 21:1586-94.

30. Aquino EML, Barreto SM, Bensenor IM, Carvalho MS, Chor D, Duncan BB, et al. Brazilian Longitudinal Study of Adult Health (ELSABrasil): objectives and design. Am J Epidemiol 2012; 175:315-24.

31. Schmidt MI, Duncan BB, Mill JG, Lotufo PA, Chor D, Barreto SM, et al. Cohort profile: Longitudinal Study of Adult Health (ELSABrasil). Int J Epidemiol 2015; 44:68-75.

32. Chor D, Alves MGM, Giatti L, Cade NV, Nunes MA, Molina MCB, et al. Questionário do ELSA-Brasil: desafios na elaboração de instrumento multidimensional. Rev Saúde Pública 2013; 47:27-36.

33. Bensenor IM, Griep RH, Pinto KA, Faria CP, Felisbino-Mendes M, Caetano EI, et al. Rotinas de organização de exames e entrevistas no centro de investigação ELSA-Brasil. Rev Saúde Pública 2013; 47:37-47.

34. Lotufo PA. Construção do Estudo Longitudinal de Saúde do Adulto (ELSA-Brasil). Rev Saúde Pública 2013; 47 Suppl 2:3-9. 
35. Schmidt MI, Griep RH, Passos VM, Luft VC Goulart AC, Menezes GM de S, et al. Estratégias e desenvolvimento de garantia e controle de qualidade no ELSA-Brasil. Rev Saúde Pública 2013 ; 47:105-12.

36. Williams DR, Gonzalez HM, Williams S, Mohammed SA, Moomal H, Stein DJ. Perceived discrimination, race and health in South Africa. Soc Sci Med 2008; 67:441-52.

37. Kass RE, Raftery AE. Bayes factors. J Am Stat Assoc 1995; 90:773.

38. Mill JG, Pinto K, Griep RH, Goulart A, Foppa $\mathrm{M}$, Lotufo PA, et al. Aferições e exames clínicos realizados nos participantes do ELSA-Brasil. Rev Saúde Pública 2013; 47:54-62.

39. Textor J, Hardt J, Knüppel S. DAGitty: a graphical tool for analyzing causal diagrams. Epidemiology 2011; 22:745.

40. Barros AJ, Hirakata VN. Alternatives for logistic regression in cross-sectional studies: an empirical comparison of models that directly estimate the prevalence ratio. BMC Med Res Methodol 2003; 3:21.

41. Brondolo E, Rieppi R, Kelly KP, Gerin W. Perceived racism and blood pressure: a review of the literature and conceptual and methodological critique. Ann Behav Med 2003; 25:55-65.

42. Paradies Y, Ben J, Denson N, Elias A, Priest N, Pieterse A, et al. Racism as a determinant of health: a systematic review and meta-analysis. PLoS One 2015; 10:e0138511.

43. Barksdale DJ, Farrug ER, Harkness K. Racial discrimination and blood pressure: perceptions, emotions, and behaviors of black American adults. Issues Ment Health Nurs 2009; 30:104-11.

44. Peters RM. Racism and hypertension among African Americans. West J Nurs Res 2004; 26:612-31.

45. Brown C. The Relation between perceived unfair treatment and blood pressure in a racially/ ethnically diverse sample of women. Am J Epidemiol 2006; 164:257-62.

46. Sims M, Diez-Roux AV, Dudley A, Gebreab S, Wyatt SB, Bruce MA, et al. Perceived discrimination and hypertension among African Americans in the Jackson Heart Study. Am J Public Health 2012; 102 Suppl 2:S258-65.

47. Ryan AM, Gee GC, Laflamme DF. The Association between self-reported discrimination, physical health and blood pressure: findings from African Americans, Black immigrants, and Latino immigrants in New Hampshire. J Health Care Poor Underserved 2006; 17(2 Suppl):116-32.
48. Behavioral Risk Factor Surveillance System. Reactions to race module, 2002 BRFSS Questionnaire. http://apps.nccd.cdc.gov/ BRFSSQuest/ListByYear.asp (accessed on 12/ Oct/2016).

49. Krieger N, Sidney S. Racial discrimination and blood pressure: the CARDIA Study of young black and white adults. Am J Public Health 1996; 86:1370-8.

50. Jones CP. Levels of racism: a theoretic framework and a gardener's tale. Am J Public Health 2000; 90:1212-5.

51. Jones CP. Invited commentary: "race", racism, and the practice of epidemiology. Am J Epidemiol 2001; 154:299-304.

52. Miranda V. A resurgence of black identity in Brazil? Evidence from an analysis of recent censuses. Demogr Res 2015; 32:1603-30.

53. Telles EE. Racismo à brasileira: uma nova perspectiva sociológica. Rio de Janeiro: Relume-Dumará; 2003.

54. Hasenbalg CA. Discriminação e desigualdades raciais no Brasil Rio de Janeiro: Edições Graal; 1979. (Biblioteca de Ciências Sociais: Série Sociologia).

55. Silva GM, Leão LTS. O paradoxo da mistura: identidades, desigualdades e percepção de discriminação entre brasileiros pardos. Rev Bras Ciênc Soc 2012; 27:117-33.

56. Nogueira O. Preconceito racial de marca e preconceito racial de origem: sugestão de um quadro de referência para a interpretação do material sobre relações raciais no Brasil. Tempo Social: Revista de Sociologia da USP 2007; 19:287-308.

57. Guimarães ASA. Intelectuais negros e formas de integração nacional. Estud Av 2004; 18:271-84.

58. Hill LK, Kobayashi I, Hughes JW. Perceived racism and ambulatory blood pressure in African American college students. J Black Psychol 2007; 33:404-21. 


\section{Resumo}

Pretos e pardos no Brasil e negros nos Estados Unidos têm risco aumentado de desenvolver hipertensão arterial, quando comparados com brancos, mas as causas dessa desigualdade ainda são pouco compreendidas. Fatores psicossociais e contextuais, inclusive discriminação racial, têm sido apontados como condições associadas a essa desigualdade. $O$ estudo teve como objetivo identificar a associação entre discriminação racial percebida e hipertensão. O estudo avaliou 14.012 participantes da linha de base do estudo ELSA-Brasil. A discriminação foi medida com a Lifetime Major Events Scale, adaptada para português. A classificação de raçal cor seguiu as categorias propostas pelo Instituto Brasileiro de Geografia e Estatística (IBGE). Hipertensão arterial foi definida de acordo com as diretrizes atuais. A associação entre a variável composta - raça/discriminação racial - e hipertensão foi estimada através de regressão de Poisson com variância robusta, e estratificada pelas categorias de indice de massa corporal (IMC) e gênero. Tendo como categoria de referência as mulheres brancas, no estrato de IMC $<25 \mathrm{~kg} / \mathrm{m}^{2}$, as mulheres pardas mostraram OR ajustada para hipertensão arterial de 1,98 (IC95\%: 1,17-3,36) e 1,3 (IC95\%: 1,131,65), respectivamente, conforme relatavam ou não a exposição à discriminação racial. Para as mulheres pretas, as ORs foram 1,9 (IC95\%: 1,422,62) e 1,72 (IC95\%: 1,36-2,18), respectivamente, para as mesmas categorias. Entre mulheres com $I M C>25 \mathrm{~kg} / \mathrm{m}^{2}$ e homens em qualquer categoria de IMC, não foi identificado nenhum efeito de discriminação racial. Apesar das diferenças nas estimativas pontuais da prevalência de hipertensão entre mulheres pardas que relataram (vs. não relataram) discriminação racial, nossos resultados são insuficientes para afirmar que existe uma associação entre discriminação racial percebida e hipertensão.

Racismo; Discriminação Social; Hipertensão

\section{Resumen}

Los "mestizos" y negros in Brasil y los negros en los EE.UU. tienen un riesgo mayor de desarrollar hipertensión que los blancos, y las causas de esta inequidad se han estudiado poco. Factores psicosociales y contextuales, incluyendo la discriminación racial, han sido identificados como las condiciones asociadas a esta inequidad. El objetivo de este estudio fue identificar la asociación entre la discriminación racial percibida y la hipertensión. El estudio evaluó a 14.012 trabajadores procedentes de la base de referencia poblacional del ELSA-Brasil. La discriminación percibida se midió mediante la Lifetime Major Events Scale, adaptada al portugués. La clasificación por raza/color siguió las categorías propuestas por el Instituto Brasileño de Geografía y Estadística. La hipertensión fue definida por criterios estándar. La asociación entre la variable compuesta -raza/discriminación racial-e hipertensión se estimó por regresión de Poisson con varianza robusta y estratificada por las categorías: índice de masa corporal (IMC) y sexo. Se eligieron mujeres blancas como grupo de referencia, en el IMC $<25 \mathrm{~kg} / \mathrm{m}^{2}$ estrato, las $\mathrm{mu}$ jeres "mestizas" mostraron una proporción de probabilidades ajustadas para hipertensión arterial de 1,98 (IC95\%: 1,17-3,36) y 1,3 (IC95\%: 1,13-1,65), respectivamente, hayan o no sufrido discriminación racial. Para las mujeres negras, la proporción de probabilidades ajustadas fueron 1,9 (IC95\%: 1,42-2,62) y 1,72 (IC95\%: 1,36-2,18), respectivamente, en las mismas categorías. Entre las mujeres con IMC > 25kg/m2 y hombres en cualquier categoría IMC, no se identificaron efectos de discriminación racial. A pesar de las diferencias en las estimaciones puntuales sobre la prevalencia de la hipertensión entre las mujeres "mestizas", que informaron y no informaron discriminación racial, nuestros resultados son insuficientes para afirmar que existe una asociación entre la discriminación racial e hipertensión.

Racismo; Discriminación Social; Hipertensión
Submitted on 24/Mar/2017

Final version resubmitted on 12/Jul/2017

Approved on 27/Jul/2017 